\title{
Electrochemical Sensors Modified with Combinations of Sulfur Containing Phthalocyanines and Capped Gold Nanoparticles: A Study of the Influence of the Nature of the Interaction between Sensing Materials
}

\author{
Ana Isabel Ruiz-Carmuega ${ }^{1}$, Celia Garcia-Hernandez ${ }^{1,2}$, Javier Ortiz ${ }^{3}$ (D), \\ Cristina Garcia-Cabezon 1,2 , Fernando Martin-Pedrosa 1,2 , Ángela Sastre-Santos 3 (D), \\ Miguel Angel Rodríguez-Perez ${ }^{2}$ (D) and Maria Luz Rodriguez-Mendez 1,2,*(D) \\ 1 Group UVASENS, Escuela de Ingenierías Industriales, Universidad de Valladolid, Paseo del Cauce, 59, \\ 47011 Valladolid, Spain; anaisabel.ruiz@uva.es (A.I.R.-C.); celiagarciahernandez@gmail.com (C.G.-H.); \\ crigar@eii.uva.es (C.G.-C.); fmp@eii.uva.es (F.M.-P.) \\ 2 BioecoUVA Research Institute, Universidad de Valladolid, 47011 Valladolid, Spain; marrod@fmc.uva.es \\ 3 Área de Química Orgánica, Instituto de Bioingeniería, Universidad Miguel Hernández de \\ Elche, 03202 Elche, Spain; jortiz@umh.es (J.O.); asastre@umh.es (Á.S.-S.) \\ * Correspondence: mluz@eii.uva.es; Tel.: +34-983-423-540
}

Received: 13 September 2019; Accepted: 16 October 2019; Published: 23 October 2019

\begin{abstract}
Voltametric sensors formed by the combination of a sulfur-substituted zinc phthalocyanine $\left(\mathrm{ZnPc}^{\mathrm{RS}}\right.$ ) and gold nanoparticles capped with tetraoctylammonium bromide (AuNP ${ }^{\mathrm{tOcBr}}$ ) have been developed. The influence of the nature of the interaction between both components in the response towards catechol has been evaluated. Electrodes modified with a mixture of nanoparticles and phthalocyanine ( $\mathrm{AuNP}{ }^{\mathrm{tOcBr}} / \mathrm{ZnPc}^{\mathrm{RS}}$ ) show an increase in the intensity of the peak associated with the reduction of catechol. Electrodes modified with a covalent adduct-both component are linked through a thioether bond-( $\left.\mathrm{AuNP}{ }^{\mathrm{tOcBr}}-\mathrm{S}-\mathrm{ZnPc}{ }^{\mathrm{R}}\right)$, show an increase in the intensity of the oxidation peak. Voltammograms registered at increasing scan rates show that charge transfer coefficients are different in both types of electrodes confirming that the kinetics of the electrochemical reaction is influenced by the nature of the interaction between both electrocatalytic materials. The limits of detection attained are 0.9 $\times 10^{-6} \mathrm{~mol} \cdot \mathrm{L}^{-1}$ for the electrode modified with the mixture $\mathrm{AuNP} \mathrm{HCcBr}^{\mathrm{tO}} \mathrm{ZnPc}{ }^{\mathrm{RS}}$ and $1.3 \times 10^{-7} \mathrm{~mol} \cdot \mathrm{L}^{-1}$ for the electrode modified with the covalent adduct $A u N P^{t O c B r}-S-Z n P c^{R}$. These results indicate that the establishment of covalent bonds between nanoparticles and phthalocyanines can be a good strategy to obtain sensors with enhanced performance, improving the charge transfer rate and the detection limits of voltammetric sensors.
\end{abstract}

Keywords: electrochemical sensor; phthalocyanine; gold nanoparticle; catechol

\section{Introduction}

Catechol is an important member of the family of phenols that can be found as an antioxidant in foods. Different types of electrodes have been described in the literature to assess the concentration of catechol in solution [1-7].

Phthalocyanines (Pcs) have attracted interest as chemical modifiers in electrochemical sensors dedicated to the detection of phenols due to their well-known electrocatalytic activity. Their electrochemical properties can be modified by introducing substituents in the aromatic ring [8-13]. Over the last decade, phthalocyanines have been linked covalently to a number of molecules, including fullerenes [14,15], perylenes [16,17], carbon-nanotubes [18,19], graphite, and nanoparticles [20-23]. 
The electrocatalytic properties of gold nanoparticles (AuNPs) are also well established [24-27], and a variety of uncapped and capped AuNPs have been successfully used to detect phenols [28-30].

One possible strategy to improve the performance of electrochemical sensors could be to develop composites formed by combinations of electrocatalytic materials, in order to generate synergistic effects [13,31,32]. Synergistic effects have been observed in AuNP/Pcs composites obtained by introduction weak interactions between both materials by means of mixing [32-34], self-assembling [35], the Langmuir-Blodgett (LB) [36,37], or electrodeposition techniques [38].

In spite of the interest in these combinations, the influence of the nature of the interaction between both components in the sensing properties remains largely unexplored.

The aim of this work is to develop new voltammetric sensors based on combinations of gold nanoparticles and sulfur-substituted zinc phthalocyanines and to analyze the electron transfer process, as well as the existence of synergistic effects between both components in the absence and presence of covalent links.

For this purpose, tetraoctylammonium bromide-gold nanoparticles (AuNP ${ }^{\mathrm{tOcBr}}$ ) and 2-\{2'-[(5"-Acetylthiopentyloxo)amino]ethoxy\}-9(10),16(17),23(24)-tri-tert-butylphthalocyaninate Zn(II) $\left(\mathrm{ZnPc}^{\mathrm{RS}}\right)$ have been synthesized. These species have the appropriate substituents necessary to obtain a covalently linked adduct in which the nanoparticles and the phthalocyanines have been linked covalently through thiol bonds ( $\left.\mathrm{AuNP}{ }^{\mathrm{tO} B \mathrm{Br}}-\mathrm{S}-\mathrm{ZnPc}^{\mathrm{R}}\right)$.

The sensing properties towards catechol of an ITO substrate modified with the adduct, have been compared with the responses of an ITO glass covered with a mixture of both components $\left(\mathrm{AuNP}{ }^{\mathrm{tOCBr}} / \mathrm{ZnPc}^{\mathrm{RS}}\right)$. In addition, the response of a mixture formed by AuNP ${ }^{\mathrm{tOcBr}}$ and a dimeric phthalocyanine where the sulfur groups are blocked $\mathrm{AuNP}{ }^{\mathrm{tOcBr}} / \mathrm{ZnPc}^{\mathrm{R}}-\mathrm{S}-\mathrm{ZnPc}{ }^{\mathrm{R}}$ have also been analyzed.

In all cases, studies at increasing scan rates have been carried out to evaluate the influence of the type of bond in the charge transfer rates. The limits of detection have also been calculated and compared.

\section{Materials and Methods}

Chemicals and solvents were of reagent grade (Aldrich Chemical Ltd., St. Louis, MO, USA). Reagents to prepare gold nanoparticles were: HAuCl4 $\times \mathrm{xH} 2 \mathrm{O}(99.9 \%$, min. $49 \%$ Au, Alfa Aesar, Haverhill, MA. USA), tetraoctylammonium bromide (98\%, Aldrich Chemical. Ltd., St. Louis, MO, USA), sodium borohydride (95\%, Riedel-de Haën, Seelze, Germany). Solutions were prepared in deionized water obtained using a Milli-Q system (Millipore, Direct-Q5, Madrid, Spain). The complete list of reactants can be found in Supplementary Materials S1.

\subsection{Synthesis of the Sensitive Materials}

Sensitive materials used in this work are depicted in Figure 1. They were synthesized as follows.

\subsubsection{Tetraoctylammonium Bromide-Capped Gold Nanoparticles (AuNP ${ }^{\mathrm{tOcBr}}$ )}

They were synthesized using the Brust method [39]. A water solution of gold tetrachloride was mixed with a toluene solution of tetraoctylammonium bromide. The mixture was stirred until the aqueous phase lost its color, and the organic phase appeared colored. Then, sodium borohydride was added drop by drop to the organic phase until a cherry color was observed. Afterwards, the mixture was stirred under nitrogen atmosphere in darkness. After decantation, gold nanoparticles capped with tetraoctylammonium bromide were obtained as a colloid in toluene. 
a)

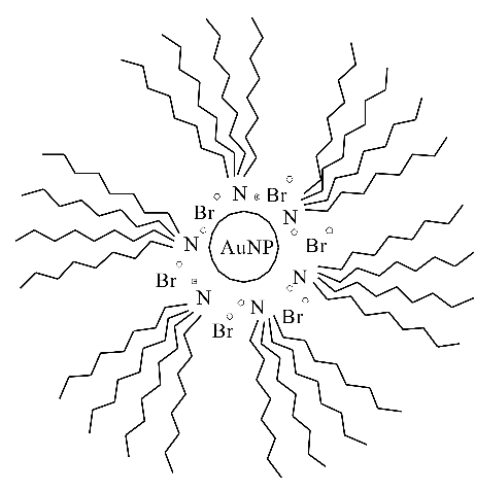

c)

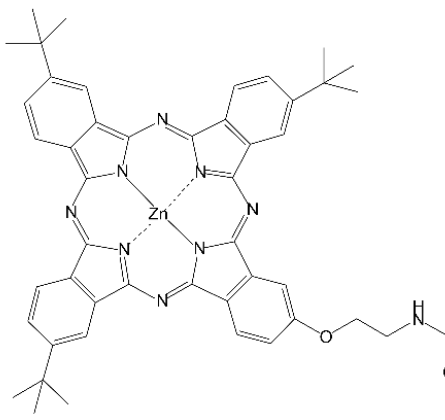

d)

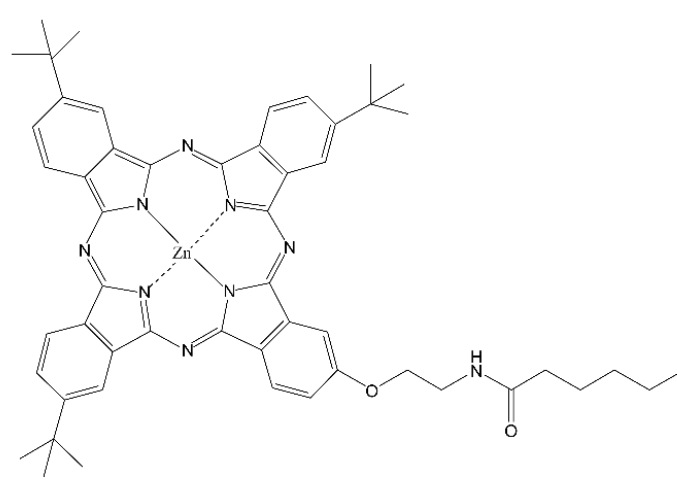

b)

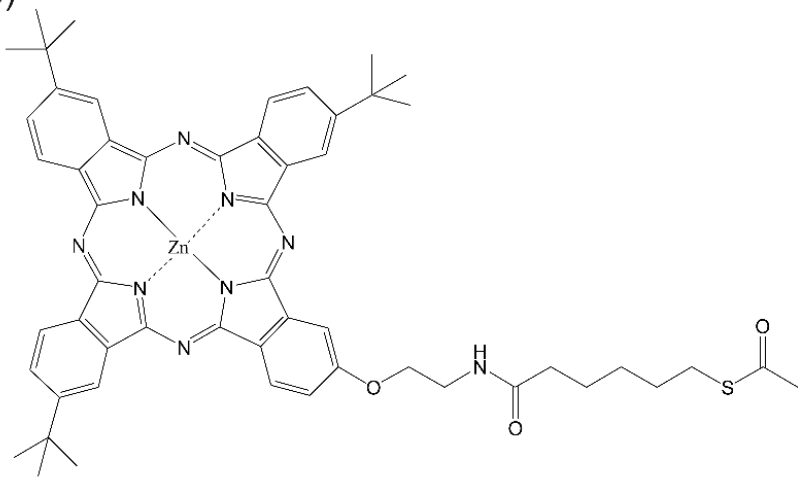

Figure 1. Scheme of the electrocatalytic materials. (a) Tetraoctylammonium bromide-capped gold nanoparticles $\left(\mathrm{AuNP}{ }^{\mathrm{tOcBr}}\right)$, (b) sulfur-substituted zinc phthalocyanine $\left(\mathrm{ZnPc}^{\mathrm{RS}}\right)$, (c) covalent adduct $\left(\mathrm{AuNP}{ }^{\mathrm{tOcBr}}-\mathrm{S}-\mathrm{ZnPc}{ }^{\mathrm{RS}}\right)$, (d) dimeric sulfur-substituted zinc bisphthalocyanine: ( $\left.\mathrm{ZnPc}^{\mathrm{R}}-\mathrm{S}-\mathrm{ZnPc}{ }^{\mathrm{R}}\right)$.

\subsubsection{6'-dithiodihexanoic Acid}

It was obtained according to a previously published method [40]. Nine hundred eighty-eight $\mathrm{mg}$ (5 mmol) of 6-bromohexanoic acid, $345 \mathrm{mg}(2.5 \mathrm{mmol})$ of $\mathrm{K}_{2} \mathrm{CO}_{3}$ and $0.5 \mathrm{~mL}$ of $\mathrm{H}_{2} \mathrm{O}$ were heated at

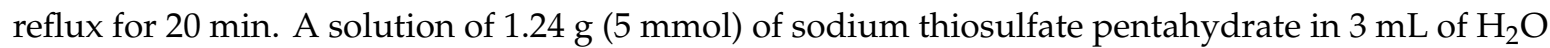
was added and the reaction was allowed to react for $1 \mathrm{~h}$ at reflux. Then $1.26 \mathrm{~g}$ (5 mmol) of iodine was added and allowed to cool for $30 \mathrm{~min}$. One hundred fifty $\mu \mathrm{L}(0.125 \mathrm{mmol})$ of concentrated $\mathrm{H}_{2} \mathrm{SO}_{4} \mathrm{was}$ added, the reaction mixture was diluted in dichloromethane (DCM) and washed with $\mathrm{H}_{2} \mathrm{O}$, extracting the aqueous phase twice with DCM. The organic phases were dried with $\mathrm{Na}_{2} \mathrm{SO}_{4}$ and the solvent was removed under reduced pressure. The reaction crude was recrystallized from hot toluene to obtain 552 $\mathrm{mg}$ of the product $(40 \%), \mathrm{mp} 76.5^{\circ} \mathrm{C}$ (toluene). ${ }^{1} \mathrm{H}-\mathrm{RMN}\left(300 \mathrm{MHz}, \mathrm{DMSO}-d_{6}, 25^{\circ} \mathrm{C}\right): \delta=1.43-1.48$ $(\mathrm{m}, 4 \mathrm{H}), 1.64-1.73(\mathrm{~m}, 8 \mathrm{H}), 2.2\left(\mathrm{t}, \mathrm{J}=7.3 \mathrm{~Hz}, 4 \mathrm{H}, \mathrm{CH}_{2} \mathrm{CO}\right), 2.5\left(\mathrm{t}, \mathrm{J}=7.3 \mathrm{~Hz}, 4 \mathrm{H}, \mathrm{CH}_{2} \mathrm{~S}\right), 11.0(\mathrm{br} \mathrm{s}, 2 \mathrm{H}$, 
$\left.2 \times \mathrm{CO}_{2} \mathrm{H}\right) \cdot{ }^{13} \mathrm{C}-\mathrm{RMN}\left(75 \mathrm{MHz}, \mathrm{DMSO}-d_{6}, 25{ }^{\circ} \mathrm{C}\right): \delta=24.1,27.3,29.3\left(3 \times \mathrm{CH}_{2}\right), 36.1\left(\mathrm{CH}_{2} \mathrm{CO}_{2} \mathrm{H}\right), 39$ $\left(\mathrm{CH}_{2} \mathrm{~S}\right)$ y $177\left(\mathrm{CO}_{2} \mathrm{H}\right)$. $v_{\max }(\mathrm{KBr}) / \mathrm{cm}^{-1}: 2933,2856,1691,1466,1434,1410,1190$ y 922.

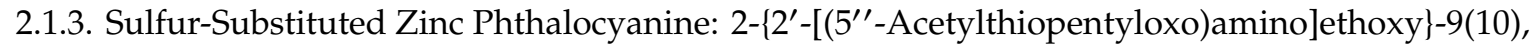
16(17),23(24)-tri-tert-butylphalocyaninate $\mathrm{Zn}(\mathrm{II})\left(\mathrm{ZnPc}^{\mathrm{RS}}\right)$

It was synthesized following a previously published procedure [21]. The corresponding dimeric structure $\left(\mathrm{ZnPc}^{\mathrm{R}}-\mathrm{S}-\mathrm{ZnPc}{ }^{\mathrm{R}}\right)$ was synthetized here for the first time using the following method.

\subsubsection{Dimeric Sulfur Substituted Zinc Bisphthalocyanine: $\left(\mathrm{ZnPc}^{\mathrm{R}}-\mathrm{S}-\mathrm{ZnPc}{ }^{\mathrm{R}}\right)$}

As mentioned before, this compound was obtained for the first time in this work. $21 \mathrm{mg}$ (0.024 mmol) of (2-aminoethoxy)-tri-tert-butylphthalocyaninate zinc (II) [16], $3.5 \mathrm{mg}$ (0.012 mmol) of $6,6^{\prime}$-dithiodihexanoic acid and $11.2 \mathrm{mg}(0.055 \mathrm{mmol})$ of dicyclohexylcarbodiimide (DCC) were dissolved in $700 \mu \mathrm{L}$ of dichloromethane under argon at $0{ }^{\circ} \mathrm{C}$. After $30 \mathrm{~min}, 1 \mathrm{mg}(0.009 \mathrm{mmol})$ of $\mathrm{N}, \mathrm{N}$-dimethylaminopyridine (DMAP) was added and allowed to react for $3 \mathrm{~h}$. The reaction mixture was diluted with dichloromethane, the organic phase was washed with $\mathrm{NH}_{4} \mathrm{Cl}$ (aq.), $\mathrm{NaHCO}_{3}$ (aq.) and $\mathrm{H}_{2} \mathrm{O}$, dried with $\mathrm{Na}_{2} \mathrm{SO}_{4}$ and the solvent was removed under reduced pressure. The crude was purified by column chromatography (dichloromethane: methanol/99:1) to obtain $14 \mathrm{mg}$ of the compound $(60 \%) .{ }^{1} \mathrm{H}-\mathrm{RMN}\left(300 \mathrm{MHz}\right.$, TFA- $\left.d_{1}, 25^{\circ} \mathrm{C}\right): \delta=1.47\left(\mathrm{~m}, 12 \mathrm{H}, 6 \times \mathrm{CH}_{2}\right) 1.68[\mathrm{br} \mathrm{s}, 54 \mathrm{H}$, 6x $\left(\mathrm{CH}_{3}\right)_{3} \mathrm{C}$ ), 2.54 (br s, $4 \mathrm{H}, \mathrm{CH}_{2} \mathrm{CO}$ ), 2.74 (br s, $\left.4 \mathrm{H}, \mathrm{CH}_{2} \mathrm{~S}\right), 4.16$ (br s, $\left.4 \mathrm{H}, \mathrm{CH}_{2} \mathrm{~N}\right), 4.68$ (br s, $4 \mathrm{H}, \mathrm{CH}_{2} \mathrm{O}$ ), $7.88(\mathrm{~m}, 3 \mathrm{H}, \mathrm{ArH}), 8.47(\mathrm{~m}, 6 \mathrm{H}, \mathrm{ArH}), 8.96(\mathrm{~m}, 2 \mathrm{H}, \mathrm{ArH})$ y $9.31-9.48(\mathrm{~m}, 13 \mathrm{H}, \mathrm{ArH}) . v_{\max }(\mathrm{KBr}) / \mathrm{cm}^{-1}$ : 3401, 2952, 2855, 1610, 1488, 1461, 1391, 1329, 1255, 1089, 1046 y $748 \mathrm{~cm}^{-1}$. UV-Vis (DMF): $\lambda \max / \mathrm{nm}$ ( $\log \varepsilon$ ): 350 (5.14), 610 (4.84), 676 (5.58). HRMS-MALDI-TOF (dithranol): $m / z$ : for $\mathrm{C}_{104} \mathrm{H}_{108} \mathrm{~N}_{18} \mathrm{O}_{4} \mathrm{~S}_{2} \mathrm{Zn}_{2}$ calcd, 1864.682; found $1864.684\left(\mathrm{M}^{+}\right)$.

\subsection{5. $\mathrm{AuNP}{ }^{\mathrm{tOcBr}} / \mathrm{ZnPc}{ }^{\mathrm{RS}}$ and $\mathrm{AuNP}{ }^{\mathrm{tOcBr}} / \mathrm{ZnPc}^{\mathrm{R}}-\mathrm{S}-\mathrm{ZnPc}^{\mathrm{R}}$ Mixtures}

The non-covalent mixture of $\mathrm{AuNP}{ }^{\mathrm{tOcBr}} / \mathrm{ZnPc}^{\mathrm{RS}}$ was prepared from $\mathrm{AuNP}{ }^{\mathrm{tOcBr}}$ toluene colloid (Abs398 $\mathrm{nm}=3,5 \mathrm{ua})$ and $\mathrm{ZnPc}^{\mathrm{RS}}\left(6.5 \times 10^{-5} \mathrm{~mol} \cdot \mathrm{L}^{-1}\right)$ mixed in a proportion of 2:1 $\left.\mathrm{v} / \mathrm{v}\right)$. The mixture was kept in the dark until used. A similar method was followed to obtain the mixture $\mathrm{AuNP}^{\mathrm{tOcBr}} / \mathrm{ZnPc}^{\mathrm{R}}-\mathrm{S}-\mathrm{ZnPc}{ }^{\mathrm{R}}$.

\subsection{6. $\mathrm{AuNP}^{\mathrm{tOcBr}}-\mathrm{S}_{-} \mathrm{ZnPc}^{\mathrm{R}}$ Covalent Adduct}

The covalent adduct (AuNP ${ }^{\mathrm{tOcBr}}-\mathrm{S}-\mathrm{ZnPc}^{\mathrm{R}}$ ) was obtained as follows [21]: $4 \mathrm{~mL}$ of the phthalocyanine toluene solution $\left(1.3 \times 10^{-3} \mathrm{~mol} \cdot \mathrm{L}^{-1}\right)$ was mixed with $4 \mathrm{~mL}$ of the nanoparticle colloid (Abs398 $\mathrm{nm}$ $=3.5 \mathrm{ua}$ ) and stirred for $24 \mathrm{~h}$ at room temperature, in darkness and under inert atmosphere. Next, the product was added to pentane drop by drop. The precipitate was dissolved in methane and kept overnight at $-20^{\circ} \mathrm{C}$. Following centrifugation, the new precipitate of $\mathrm{AuNP}{ }^{\mathrm{tO} B \mathrm{cr}}-\mathrm{S}-\mathrm{ZnPc}{ }^{\mathrm{R}}$ was re-suspended in toluene.

\subsection{Preparation of the Sensors}

Sensors were prepared by depositing a layer of the mixtures or of the adduct by spin coating (spin coater model 1H-D7, Micasa Co., Tokyo, Japan). Before deposition, ITO glass substrates were washed with acetone and rinsed twice with deionized water in an ultrasonic bath. Fifty $\mu \mathrm{L}$ of the corresponding material was deposited onto the substrate $\left(1 \mathrm{~cm}^{2}\right.$ surface $)$ using $120 \mathrm{~s}$ slope and $120 \mathrm{~s}$ at $1000 \mathrm{rpm}$.

The sensing materials and films were characterized by TEM microscopy (JEOL-FS2200 HRP. $200 \mathrm{kV}$ emission) and UV-Vis spectroscopy with a double beam spectrophotometer (UV-2600, Shimadzu, Kyoto, Japan). 


\subsection{Sensing Properties}

Cyclic voltammetry was used to characterize the sensing behavior of the chemically modified films. Electrochemical measurements were carried out in a Parstat 2273 (Princeton Applied Research) using a three-electrode cell. The reference electrode was $\mathrm{Ag} \mid \mathrm{AgCl} / \mathrm{KCl}$ sat. and the counter electrode was a platinum sheet. Modified ITO films were used as working electrodes. The electrochemical responses were analyzed towards catechol $10^{-3} \mathrm{~mol} \cdot \mathrm{L}^{-1}$ in phosphate buffer $\left(\mathrm{Na}_{2} \mathrm{HPO}_{4} / \mathrm{NaH}_{2} \mathrm{PO}_{4} 0.01 \mathrm{M} \mathrm{pH}=7\right)$. Cyclic voltammograms were registered from -0.8 to $1.2 \mathrm{~V}$ at a scan rate of $0.1 \mathrm{~V} \cdot \mathrm{s}^{-1}$. The Limits of detection (LOD) were calculated from peak current responses in voltammograms registered at concentrations from $4 \times 10^{-6}$ to $1.45 \times 10^{-4} \mathrm{~mol} \cdot \mathrm{L}^{-1}$ following the " $3 \mathrm{Sd} / \mathrm{m}^{\prime}$ method, where " $\mathrm{Sd}^{\text {" is }}$ the standard deviation ( $n=5$ ) of the signal registered in the buffer, and " $\mathrm{m}$ " is the slope of the calibration curve. The influence of the potential sweep rate was studied in catechol $10^{-4} \mathrm{~mol} \cdot \mathrm{L}^{-1}$ changing the scan rates from 0.01 to $1.0 \mathrm{~V} \cdot \mathrm{s}^{-1}$.

\section{Results and Discussion}

The UV-Vis spectra of the individual sensing materials are shown in Figure 2a. The electronic absorption spectrum of the AuNP ${ }^{\mathrm{tOcBr}}$ colloid was dominated by an intense peak at $398 \mathrm{~nm}$ produced by the plasmon resonance, accompanied by a small shoulder at $485 \mathrm{~nm}$. The sharpness of the peak at $398 \mathrm{~nm}$ reflected a homogeneous distribution of the NPs size. The colloid diluted 1:10, showed the same features as the undiluted colloid, confirming the lack of aggregation. UV-Vis spectra of the $\mathrm{ZnPc}{ }^{\mathrm{RS}}$ toluene solutions showed the expected $Q$ bands at $689 \mathrm{~nm}$ and at $675 \mathrm{~nm}$ which are usually observed in unsymmetrical phthalocyanines. The spectrum also exhibited an intense Soret band at $353 \mathrm{~nm}$ and a small vibronic band at $618 \mathrm{~nm}$. The spectrum of the dimeric phthalocyanine was similar to the one observed in the monomeric form. The only differences were found in the intensity of the $\mathrm{Q}$ and Soret bands which were more intense in the dimeric compound due to the presence of two phthalocyanine rings. The UV-Vis spectra of the mixtures and of the adduct are presented in Figure $2 \mathrm{~b}$. The spectrum of the $\mathrm{AuNP} \mathrm{tOcBr}^{\mathrm{tOnPC}} \mathrm{ZnS}^{\mathrm{RS}}$ mixture showed bands associated with each one of the components, although changes in the intensities and positions of the peaks with respect to those observed in the spectra of the individual components were observed: The $Q$ band of the phthalocyanine appeared at $679 \mathrm{~nm}$. Due to its broadness, the splitting was no longer observed. Furthermore, the Soret band increased its intensity with respect to the $Q$ band, and appeared at $359 \mathrm{~nm}$, overlapping with the plasmonic band of the nanoparticle.
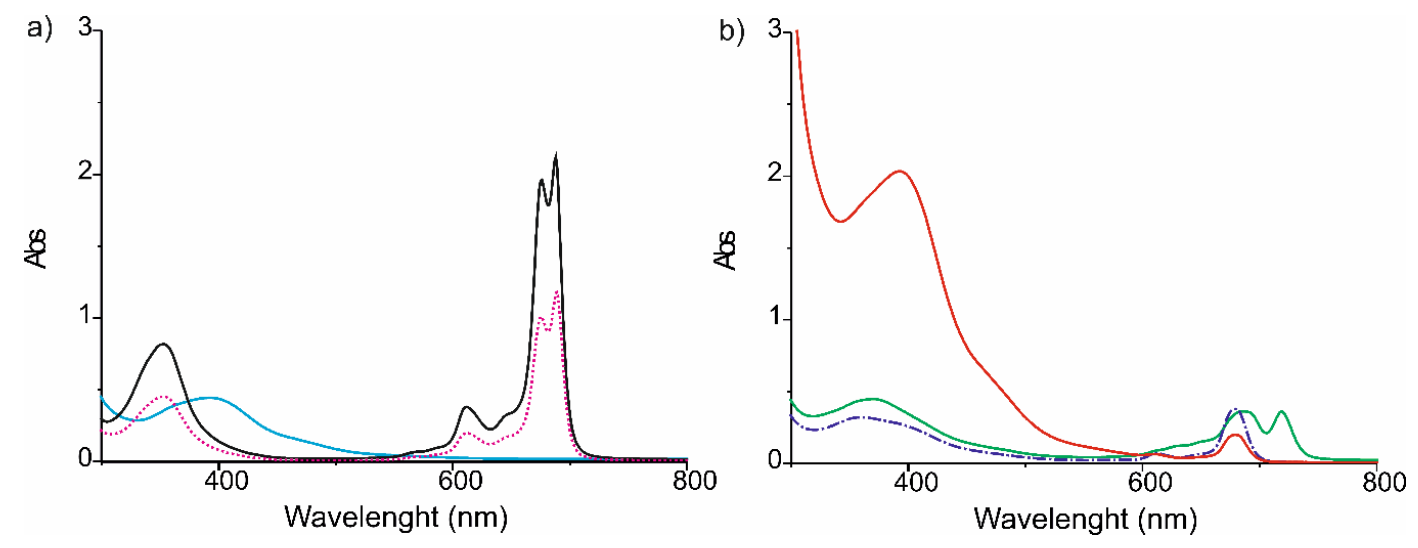

Figure 2. UV-Vis absorption spectra of (a) $\mathrm{AuNP}^{\mathrm{tOcBr}}$ (blue -), $\mathrm{ZnPc}^{\mathrm{RS}}$ (pink …..), $\mathrm{ZnPc}^{\mathrm{R}}-\mathrm{S}-\mathrm{ZnPc}^{\mathrm{R}}$ (black-) and of (b) the mixture AuNP ${ }^{\mathrm{tOcBr}} / \mathrm{ZnPc}^{\mathrm{RS}}$ (purple ----.), the mixture AuNP ${ }^{\mathrm{tOcBr}} / \mathrm{ZnPc}^{\mathrm{R}}-\mathrm{S}_{-} \mathrm{ZnPc}^{\mathrm{R}}$ (green -) and the covalent adduct $\mathrm{AuNP}^{\mathrm{tOcBr}}-\mathrm{S}-\mathrm{ZnPc}^{\mathrm{R}}$ (red -), in toluene as solvent.

The UV-Vis spectrum of the covalent adduct AuNP ${ }^{\mathrm{tOcBr}}-\mathrm{S}-\mathrm{ZnPc}^{\mathrm{R}}$ showed the same features as shown by the mixture. However, a clear increase in the intensity of the band at $393 \mathrm{~nm}$ produced by 
the overlapping of the phthalocyanine Soret band and the band of the AuNPtOcBr plasmon band was observed. This effect was consistent with a covalent interaction between the phthalocyanine and the nanoparticle that caused the modification of the $\pi-\pi$ transition.

The mixture with the dimer AuNPtOcBr $/ \mathrm{ZnPc}^{\mathrm{R}}-\mathrm{S}-\mathrm{ZnPc}^{\mathrm{R}}$ showed two broad $\mathrm{Q}$ bands. The first broadband at $685 \mathrm{~nm}$ is produced by the substituted Pc ring similar to that observed in the monomeric species. The splitting observed in the monomer cannot be observed due to the broadness of the band. The second band at $719 \mathrm{~nm}$ is typical of the formation of J aggregates due to the interaction between the two Pc rings. The Soret band appears overlapped with the band corresponding to the plasmon resonance of the nanoparticles. Obviously, a covalent adduct could not be obtained by reaction of the dimer and the AuNPs because the covalent bond was not accessible.

According to TEM images (Figure 3), the estimated core diameter of the AuNP ${ }^{\mathrm{tOcBr}}$ was $2-3 \mathrm{~nm}$. The images of the mixtures $\mathrm{AuNP}{ }^{\mathrm{tOcBr}} / \mathrm{ZnPc}^{\mathrm{RS}}$ and of the adduct $\mathrm{AuNP}^{\mathrm{tOcBr}}-\mathrm{S}-\mathrm{ZnPc}{ }^{\mathrm{R}}$ showed nanoparticles with sizes ranging from 2 to $5 \mathrm{~nm}$, with an average value of $4 \mathrm{~nm}$. The images also revealed the existence of a light halo surrounding the nanoparticles, which was due to the phthalocyanines located around nanoparticles. The thickness of the halo was smaller in the case of the mixtures AuNP ${ }^{\mathrm{tOcBr}} / \mathrm{ZnPc} c^{\mathrm{RS}}$ and $\mathrm{AuNP}{ }^{\mathrm{tOcBr}} / \mathrm{ZnPc}^{\mathrm{R}}-\mathrm{S}-\mathrm{ZnPc}^{\mathrm{R}}$ films and could only be observed at higher magnifications.

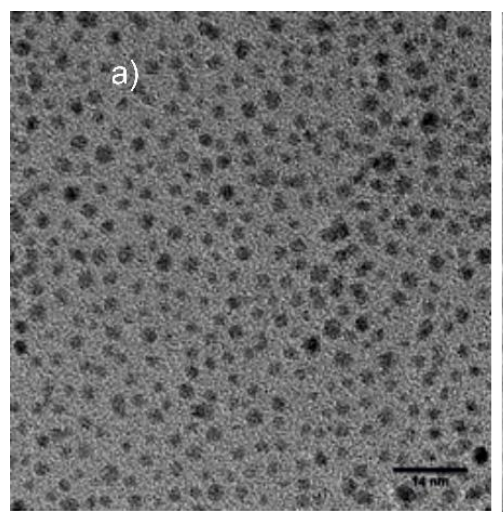

Figure 3. TEM images of (a) AuNP ${ }^{\mathrm{tOcBr}}$ $\mathrm{AuNP} \mathrm{tOcBr}_{-} \mathrm{S}-\mathrm{ZnPc}{ }^{\mathrm{R}}$.

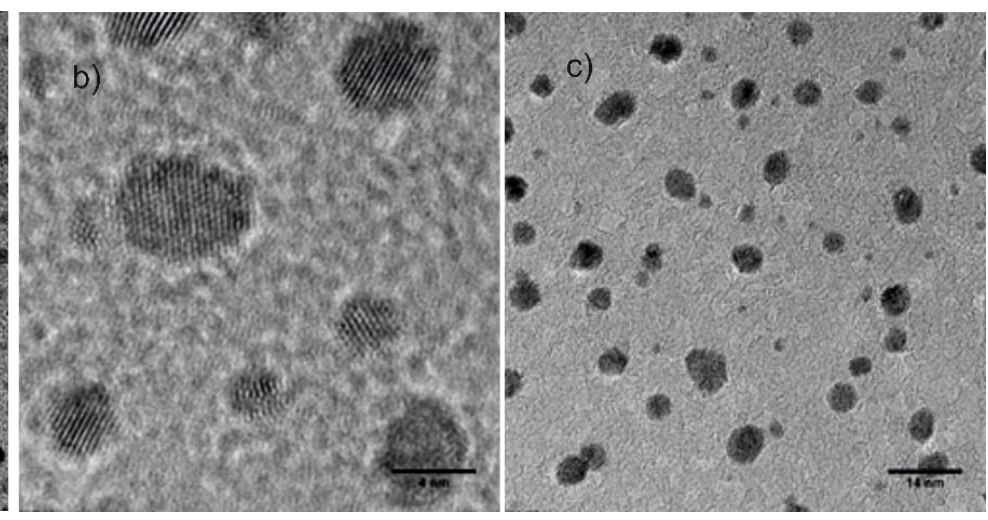

(b) mixture AuNPtOcBr$/ \mathrm{ZnPc}^{\mathrm{RS}}$, and (c) adduct

ITO glasses were modified with spin-coated films of the $A u N P^{t O c B r} / Z n P c^{R S}$, $\mathrm{AuNP}^{\mathrm{tOcBr}} / \mathrm{ZnPc}^{\mathrm{R}}-\mathrm{S}-\mathrm{ZnPc}{ }^{\mathrm{R}}$ mixtures and of the $\mathrm{AuNP}^{\mathrm{tO} c \mathrm{Br}}-\mathrm{S}-\mathrm{ZnPc}^{\mathrm{R}}$ adduct. Their sensing properties towards catechol were analyzed using cyclic voltammetry. The electrochemical responses of a bare ITO and films prepared from individual components $A u N P^{t O c B r}, \mathrm{ZnPc}^{\mathrm{RS}}$, and $\mathrm{ZnPc}^{\mathrm{R}}-\mathrm{S}-\mathrm{ZnPc}{ }^{\mathrm{R}}$ were also analyzed for comparison purposes.

Voltammetric responses towards a $10^{-3} \mathrm{~mol} \cdot \mathrm{L}^{-1}$ catechol solution (in $0.01 \mathrm{M}$ phosphate buffer as electrolyte $\mathrm{pH}=7$ ) are shown in Figure 4. As a general rule, responses were characterized by an anodic peak at positive potentials (produced by the oxidation of catechol to 1, 2 benzoquinone) and a cathodic peak at ca. $-0.25 \mathrm{~V}$ produced by the corresponding reduction of the benzoquinone. However, important differences were caused by the modification of the electrode.

When a bare ITO electrode was immersed in catechol, peaks were quite weak. A small increase in the intensity of the peaks was observed when the ITO glass was coated with AuNP ${ }^{\mathrm{tOcBr}}$. In contrast, $\mathrm{ZnPc}^{\mathrm{RS}}$ coated ITO glass produced an increase in the intensity of the anodic wave (from $3 \mu \mathrm{A}$ in ITO to $30 \mu \mathrm{A}$ in films coated with $\mathrm{ZnPc}^{\mathrm{RS}}$ ). The cathodic peak also increased from $-7 \mu \mathrm{A}$ to $-45 \mu \mathrm{A}$. The observed increase proved the electrocatalytic properties of the zinc phthalocyanine derivative. 

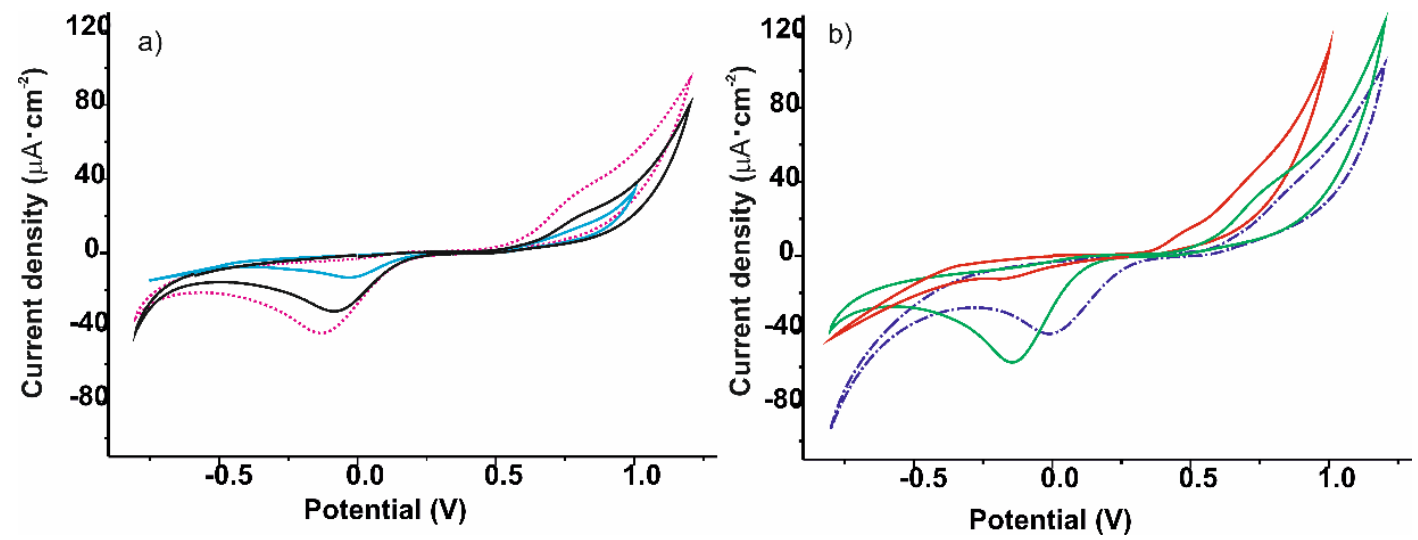

Figure 4. Cyclic voltammograms registered in catechol $10^{-3} \mathrm{~mol} \cdot \mathrm{L}^{-1}(0.01 \mathrm{M}$ phosphate buffer as electrolyte using (a) AuNP ${ }^{\mathrm{tOcBr}}$ (blue -), $\mathrm{ZnPc}^{\mathrm{RS}}$ (pink …...), $\mathrm{ZnPc}^{\mathrm{R}}-\mathrm{S}-\mathrm{ZnPc}^{\mathrm{R}}$ (black -) and of (b) the mixture AuNP ${ }^{\mathrm{tOcBr}} / \mathrm{ZnPc}^{\mathrm{RS}}$ (purple --.-.), the mixture $\mathrm{AuNP}{ }^{\mathrm{tOCBr}} / \mathrm{ZnPc}^{\mathrm{R}}-\mathrm{S}-\mathrm{ZnPc}^{\mathrm{R}}$ (green - ) and the covalent adduct AuNP ${ }^{\mathrm{tOcBr}}-\mathrm{S}-\mathrm{ZnPc}^{\mathrm{R}}$ (red -), Scan rate $100 \mathrm{mV} \cdot \mathrm{s}^{-1}$.

Voltammograms obtained using electrodes modified with the $\mathrm{AuNP} \mathrm{tcBr}^{\mathrm{tO}} / \mathrm{ZnPc}^{\mathrm{RS}}$ mixture also showed the expected anodic and cathodic waves. The anodic peak was almost identical to that obtained with $\mathrm{ZnPc}{ }^{\mathrm{RS}}$ alone, indicating that the influence on the electrocatalytic behavior of the $\mathrm{AuNP}^{\mathrm{tOcBr}}$ present in the mixture was almost negligible. In contrast, the position of the cathodic peak shifted to lower potentials and the mixture of compounds seemed to show a stronger electrocatalytic effect than the components separately. The mixture of gold nanoparticles with the dimeric species $\mathrm{AuNP}{ }^{\mathrm{tOcBr}} / \mathrm{ZnPc}^{\mathrm{R}}-\mathrm{S}-\mathrm{ZnPc}{ }^{\mathrm{R}}$, produced a higher increase in the intensity of the cathodic wave than the mixture of the nanoparticle with the monomeric phthalocyanine. This could be due to the stronger interaction between the phthalocyanine rings and the gold NPs.

Responses observed using electrodes modified with the covalent adduct $\mathrm{AuNP}^{\mathrm{tOcBr}}-\mathrm{S}-\mathrm{ZnPc}{ }^{\mathrm{R}}$ differed from those obtained with the $\mathrm{AuNP} \mathrm{PcBr}^{\mathrm{tO}} / \mathrm{ZnPc}^{\mathrm{RS}}$ mixture. The main difference was observed in the anodic peak that showed an important shift to lower potentials. In contrast, the electrocatalytic effect disappeared completely in the cathodic peak.

The important differences between the mixture and the adduct confirm the importance of the nature of the interaction between the phthalocyanine and the gold nanoparticle in the electrocatalytic mechanism.

In order to further analyze the effect of the modifiers on the dynamic character of the electrochemical process, voltammograms were registered at different scan rates (from 0.01 to $1.0 \mathrm{~V} \cdot \mathrm{s}^{-1}$ ). Experiments were carried out in catechol $10^{-4} \mathrm{~mol} \cdot \mathrm{L}^{-1}$ (in phosphate buffer $0.01 \mathrm{M}, \mathrm{pH}=7$ ). In all cases, the intensity of the peaks increased with the scan rate. Simultaneously, cathodic peaks shifted to more negative potentials while anodic peaks shifted to more positive potentials.

According to the literature, when the peak current varies linearly with the sweep rate $(v)$, the transfer of the electrons from the analyte to the electrode is the limiting step of the process. If the peak current varies linearly with the square root of the scan rate $\left(v^{1 / 2}\right)$, the electrode reaction is controlled by diffusion. Figure 5 shows the analysis of the dynamic behavior of the sensor based on the mixture AuNPtOcBr/ZnPcR-S-ZnPcR. Figure 5a shows the relationship between the current density and the sweep rate $(v)$, according to the Laviron model (Equation (1)) and Figure $5 \mathrm{~b}$ shows the relationship between the current density and the square root of the scan rate $\left(v^{1 / 2}\right)$ according to the Randles-Sevcik model (Equation (2)). Slopes and correlation coefficients for all the sensors are collected in Table 1.

$$
\begin{gathered}
I c=\frac{n^{2} F^{2} v \Gamma A}{4 R T} \\
I c=0.446 F A \sqrt{\frac{F D v}{R T}}[C]
\end{gathered}
$$


where $I_{c}$ is the peak current, $n$ is the number of electrons involved in the process, $F$ is the Faraday's constant, $v$ is the scan rate (expressed in $\mathrm{V} \cdot \mathrm{s}^{-1}$ ), $\Gamma$ is the surface coverage of the electrode reaction substance $\left(\mathrm{mol} \mathrm{cm}{ }^{-2}\right), A$ is the electrode area $\left(\mathrm{cm}^{2}\right), R$ is the ideal gas constant $\left(8.314 \mathrm{~J} \cdot \mathrm{mol}^{-1} \cdot \mathrm{K}^{-1}\right)$, $T$ is the temperature ( $298 \mathrm{~K})$. $D$ is the diffusion coefficient, $[C]$ the bulk concentration of species $C$ in the solution.
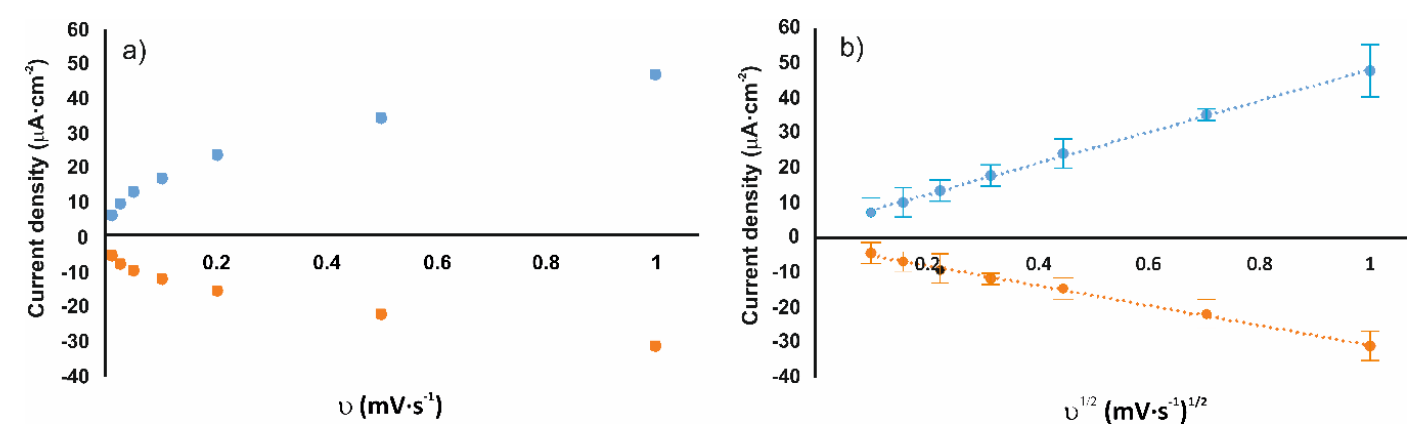

Figure 5. Analysis of the dynamic behavior of the sensor based on the mixture AuNP ${ }^{\mathrm{tOcBr}} / \mathrm{ZnPc}^{\mathrm{R}}-\mathrm{S}-\mathrm{ZnPc} \mathrm{C}^{\mathrm{R}}$ (a) Laviron model, graphical relationship between the current peak density and the sweep rate $(v),(\mathbf{b})$ Randles-Sevcik model peak current density varies linearly with the square root of the scan rate $\left(v^{1 / 2}\right)$.

Table 1. Relationship between the intensity of the peaks and the scan rate in sensors immersed in $10^{-4} \mathrm{~mol} \cdot \mathrm{L}^{-1}$ catechol. (Results shown correspond to the average values obtained from three different experiments).

\begin{tabular}{|c|c|c|c|c|c|c|}
\hline \multicolumn{7}{|c|}{ Cathodic Wave at ca. $-0.15 \mathrm{~V}$} \\
\hline & \multicolumn{3}{|c|}{$\begin{array}{l}\text { Laviron Model: } I=\mathrm{f}(v), \\
I_{c}\left(\mu \mathrm{A} \cdot \mathrm{cm}^{-2}\right) \text { vs. } v(\mathrm{~V} / \mathrm{s})\end{array}$} & \multicolumn{3}{|c|}{$\begin{array}{c}\text { Randless-Sevcik Model } \\
I=\mathrm{f}(\operatorname{sqrt}(v)) \\
I_{\mathcal{c}}\left(\mu \mathrm{A} \cdot \mathrm{cm}^{-2}\right) \text { vs. } v^{1 / 2}(\mathrm{~V} / \mathrm{s})^{1 / 2}\end{array}$} \\
\hline Sensor & Slope & Intercept & $\mathbf{R}^{2}$ & Slope & Intercept & $\mathbf{R}^{2}$ \\
\hline $\mathrm{AuNP} \mathrm{tOcBr}_{\mathrm{ZnPc}}^{\mathrm{RS}}$ & -19.32 & -6.11 & 0.993 & -21.31 & -2.32 & 0.973 \\
\hline $\mathrm{AuNP}{ }^{\mathrm{tOcBr}} / \mathrm{ZnPc}^{\mathrm{R}}-\mathrm{S}-\mathrm{ZnPc} \mathrm{c}^{\mathrm{R}}$ & -24.78 & -7.59 & 0.953 & -28.26 & -2.34 & 0.997 \\
\hline $\mathrm{AuNP}^{\mathrm{tOcBr}}-{ }_{-}-\mathrm{ZnPc}^{\mathrm{R}}$ & -54.46 & -5.33 & 0.915 & -31.65 & -1.64 & 0.982 \\
\hline \multicolumn{7}{|c|}{$\begin{array}{l}\text { Anodic wave at ca. } 0.8 \mathrm{~V} \\
I_{c}\left(\mu \mathrm{A} \cdot \mathrm{cm}^{-2}\right) \text { vs. } v(\mathrm{~V} / \mathrm{s})\end{array}$} \\
\hline Sensor & Slope & Intercept & $\mathbf{R}^{2}$ & Slope & Intercept & $\mathbf{R}^{2}$ \\
\hline $\mathrm{AuNP} \mathrm{tOcBr}_{\mathrm{ZnPc}}^{\mathrm{RS}}$ & 42.12 & 6.34 & 0.980 & 37.20 & -0.06 & 0.962 \\
\hline AuNPtOcBr$/ \mathrm{ZnPc}^{\mathrm{R}}-\mathrm{S}-\mathrm{ZnPc} \mathrm{c}^{\mathrm{R}}$ & 38.85 & 11.71 & 0.935 & 44.76 & 3.30 & 0.998 \\
\hline $\mathrm{AuNP}{ }^{\mathrm{tOcBr}}-\mathrm{S}-\mathrm{ZnPc} \mathrm{C}^{\mathrm{R}}$ & 210.91 & 10.45 & 0.934 & 92.17 & 1.82 & 0.987 \\
\hline
\end{tabular}

As observed in Figure 5 and Table 1, correlation coefficients $R^{2}$ show that both models, Laviron and Randless-Sevcik could explain the dynamic behavior of the sensors. This is quite common in chemically modified electrodes immersed in electroactive solutions. However, the fitting is clearly linear in the diffusion-controlled model.

In order to further analyze the nature of the limiting step of the electrode reaction, the relationship between $\mathrm{I} / v^{1 / 2}$ vs. $v$ was analyzed. If this relationship is linear, the mechanism that controls the redox process is the charge transfer of the adsorbate. On the contrary, when the current function $\mathrm{I} / \mathrm{v}^{1 / 2}$ is independent of the scan rate, the predominant mechanism is diffusion. In this case, all sensors showed a combination of both mechanisms: At low scan rates (lower than $0.20 \mathrm{~V} \cdot \mathrm{s}^{-1}$ ), the charge transfer predominated. At scan rates over $0.20 \mathrm{~V} \cdot \mathrm{s}^{-1}$, the process was limited by diffusion (Figure 6). 

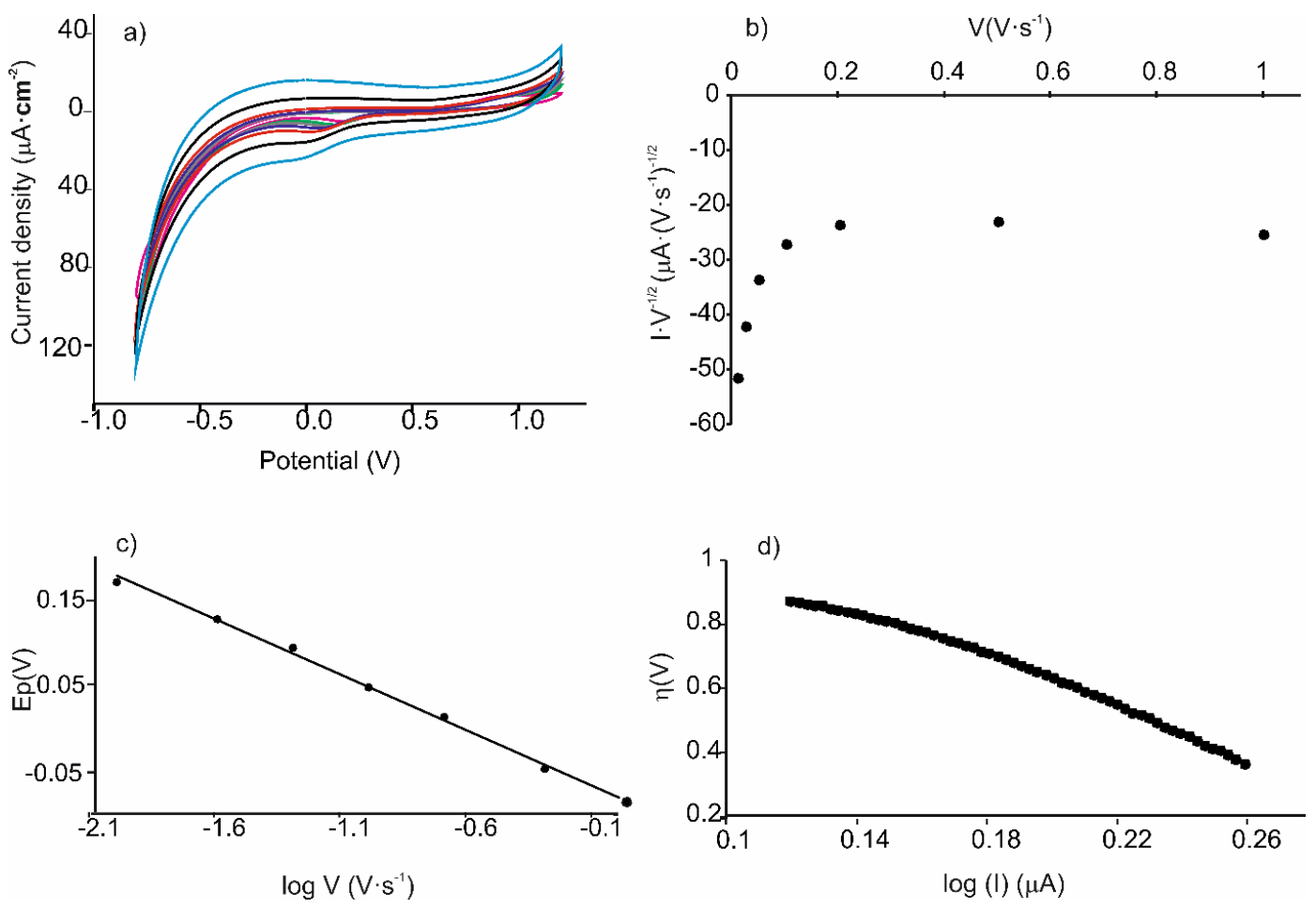

Figure 6. Analysis of the electron transfer mechanism. (a) Cyclic voltammograms of AuNPtOcBr $/ \mathrm{ZnPc}^{\mathrm{RS}}$ in catechol $10^{-4} \mathrm{~mol} \cdot \mathrm{L}^{-1}$ registered at increasing scan rates from 0.01 to $1 \mathrm{~V} \cdot \mathrm{s}^{-1}$, (b) representation of $\mathrm{I} \cdot v^{-1 / 2}$ vs. scan rate for the cathodic pea, (c) variation of peak potentials vs. the logarithm of the scan rates. (d) Representation of Tafel plot: overpotential $\eta$ vs $\log (\mathrm{I})$ in cathodic peak.

At scan rates lower than $0.20 \mathrm{~V} \cdot \mathrm{s}^{-1}$, where the charge transfer is the limiting step, the charge transfer coefficient $\alpha$ can be calculated from the slope of the Laviron equation (Equation (3)). This coefficient is related to the efficiency of the electron transfer between the electrode and the surface-confined redox couple [36],

$$
E_{c}=E^{0}-\frac{2.3 R T}{\left(\alpha_{c}\right) n F} \log v
$$

where $E_{c}$ is the cathodic peak potential, $E^{0}$ is a constant that includes the formal standard potential, $R$ is the ideal gas constant $\left(8.314 \mathrm{~J} \cdot \mathrm{mol}^{-1} \cdot \mathrm{K}^{-1}\right), T$ is the temperature $(298 \mathrm{~K}), \alpha_{c}$ is the charge transfer coefficient, $n$ is the number of electrons involved in the process, $F$ is the Faraday's constant and $v$ is the scan rate (expressed in $\mathrm{V} \cdot \mathrm{s}^{-1}$ ).

Our results showed that the slope of the $E_{c}$ vs. $\log v$ gave $\alpha$ n values between 0.43 and 0.45 (Table 2).

Table 2. Relationship with scan rate in sensors immersed in catechol $10^{-4} \mathrm{~mol} \cdot \mathrm{L}^{-1}$.

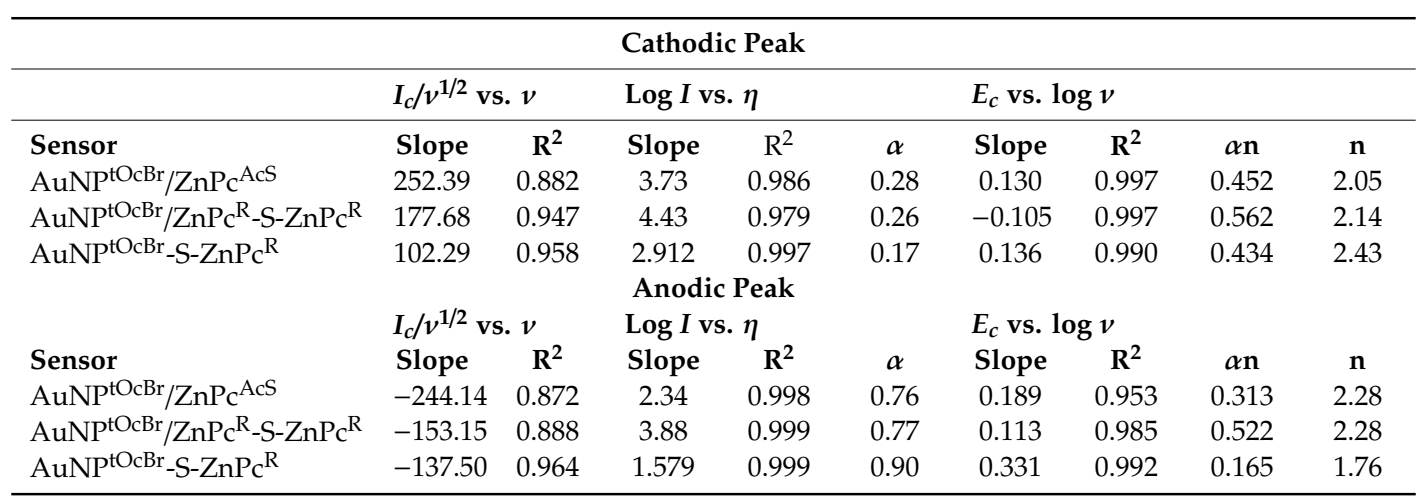


In order to obtain information about the efficiency of the catalyst and the rate-determining step, representation of $\log I(\mu \mathrm{A})$ vs. the overpotential, $\eta(\mathrm{V})$, Tafel plot was used to calculate values thanks to the simplified Butler-Volmer equation (Equation (4).

$$
\log I=\log I_{0}-\frac{\alpha F}{2.3 R T} \eta
$$

The $\alpha$ values obtained can be substituted in Laviron's equation to calculate the number of electrons implicated in the redox process. All these values are listed in Table 2. Calculations indicate a two-electron redox reaction of catechol at all three electrodes.

Similar calculations were carried out using the anodic peak (Equation (5) and (6)) where $E_{a}$ is the anodic peak potential.

$$
\begin{aligned}
& E_{a}=E^{0}-\frac{2.3 R T}{(1-\alpha) n F} \log v \\
& \log I=\log I_{0}-\frac{(1-\alpha) F}{2.3 R T} \eta
\end{aligned}
$$

As observed in the table, the charge transfer coefficient $\alpha$, showed different values in the $\mathrm{AuNP}{ }^{\mathrm{tOcBr}} / \mathrm{ZnPc}^{\mathrm{RS}}$ composite than in the AuNP ${ }^{\mathrm{tOcBr}}-\mathrm{S}-\mathrm{ZnPc}^{\mathrm{R}}$ adduct, confirming the different mechanism of the reduction process. It is noteworthy that the behavior of the mixture containing the dimer ( $\mathrm{AuNP} \mathrm{tOcBr}^{\mathrm{tOn}} \mathrm{Znc}^{\mathrm{R}}-\mathrm{S}-\mathrm{ZnPc}^{\mathrm{R}}$ ) where the thiol group is protected coincided with that of the mixture AuNP ${ }^{\mathrm{tOcBr}} / \mathrm{ZnPc}^{\mathrm{RS}}$. This confirms that the interaction between the phthalocyanine and the nanoparticle did not occur through thiol bonds.

The limits of detection (LOD) were calculated from voltammograms registered in solutions with increasing concentrations of catechol (from $4.0 \times 10^{-6}$ to $1.40 \times 10^{-4} \mathrm{~mol} \cdot \mathrm{L}^{-1}$ ). Experiments were replicated three times for each sensor. As expected, the intensity of the peaks increased with the concentration and the responses were linear in the studied range (Figure 7). Calibration curves were constructed by representing $I_{a}$ (or $I_{\mathcal{c}}$ ) vs. catechol concentration. Sensitivity and LODs were calculated from those plots. The results are shown in Table 3. As expected, and according to the $\alpha$ parameters obtained from the experiments carried out at different sweep rates, the presence or absence of a covalent bond influenced the sensitivities and the LODs.
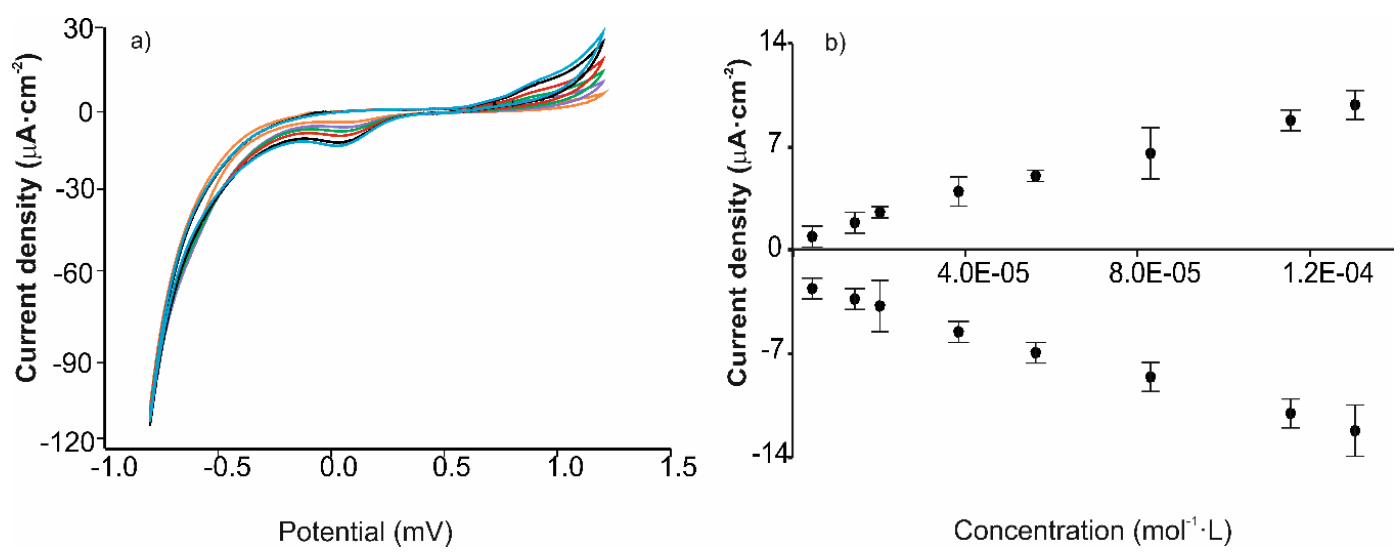

Figure 7. Analysis of limits of detection. (a) Voltammetric response of the AuNPtOcBr $/ \mathrm{ZnPc}^{\mathrm{AcS}}$ sensor to increasing concentrations of catechol (from $4 \times 10^{-6}$ to $1.40 \times 10^{-4} \mathrm{~mol} \cdot \mathrm{L}^{-1}$ in phosphate buffer), (b) calibration curves calculated in both the anodic and the cathodic peaks. 
Table 3. Sensitivity, limit of detection (LD) and correlation coefficient $\left(\mathrm{R}^{2}\right)$.

\begin{tabular}{|c|c|c|c|c|}
\hline & Sensor & $\begin{array}{c}\text { Sensitivity } \\
\left(\mu \mathrm{A} \cdot \mathrm{cm}^{-2} / \mathrm{mol}^{-\mathrm{L}^{-1}}\right)\end{array}$ & $\begin{array}{c}\text { LOD } \\
\left(\times 10^{-6} \mathrm{~mol} \cdot \mathrm{L}^{-1}\right)\end{array}$ & $\mathbf{R}^{2}$ \\
\hline \multirow{5}{*}{ Cathodic peak } & $\mathrm{AuNP} \mathrm{tOcBr}^{\mathrm{tO}}$ & $-23,747$ & 4.0 & 0.992 \\
\hline & $\mathrm{ZnPc}{ }^{\mathrm{RS}}$ & $-87,223$ & 2.0 & 0.987 \\
\hline & $\mathrm{AuNP} \mathrm{P}^{\mathrm{tOcBr}} / \mathrm{ZnPc} \mathrm{c}^{\mathrm{RS}}$ & $-76,350$ & 0.9 & 0.997 \\
\hline & $\mathrm{AuNP}{ }^{t \mathrm{OCBr}} / \mathrm{ZnPc}^{\mathrm{R}}-\mathrm{S}-\mathrm{ZnPc}{ }^{\mathrm{R}}$ & $-99,039$ & 1.2 & 0.989 \\
\hline & $\mathrm{AuNP} \mathrm{PcBr}_{-} \mathrm{S}_{-} \mathrm{ZnPc}_{\mathrm{c}}^{\mathrm{R}}$ & $-32,419$ & 8.3 & 0.989 \\
\hline \multirow{5}{*}{ Anodic peak } & $\mathrm{AuNP} \mathrm{tOcBr}^{\mathrm{t}}$ & 10,539 & 4.4 & 0.992 \\
\hline & $\mathrm{ZnPc}^{\mathrm{RS}}$ & 28,343 & 2.9 & 0.985 \\
\hline & $\mathrm{AuNP} \mathrm{PCcBr}_{\mathrm{t}}^{\mathrm{ZnPc}} \mathrm{c}^{\mathrm{RS}}$ & 68,170 & 2.2 & 0.994 \\
\hline & $\mathrm{AuNP} \mathrm{PcBr}^{\mathrm{O}} / \mathrm{ZnPc}^{\mathrm{R}}-\mathrm{S}-\mathrm{ZnPc} \mathrm{c}^{\mathrm{R}}$ & 44,337 & 2.07 & 0.981 \\
\hline & $\mathrm{AuNP}{ }^{\mathrm{tOcBr}}-\mathrm{S}-\mathrm{ZnPc} \mathrm{c}^{\mathrm{R}}$ & 45,498 & 0.13 & 0.993 \\
\hline
\end{tabular}

According to Table 3, LODs obtained from the cathodic curves were lower in sensors modified with the mixtures $\left(0.9 \times 10^{-6} \mathrm{M}\right.$ for $\mathrm{AuNP}{ }^{\mathrm{tOcBr}} / \mathrm{ZnPc}^{\mathrm{RS}}$ and $1.2 \times 10^{-6} \mathrm{M}$ AuNP $\left.{ }^{\mathrm{tOcBr}} / \mathrm{ZnPc}^{\mathrm{R}}-\mathrm{S}-\mathrm{ZnPc}^{\mathrm{R}}\right)$. These values were quite similar to those obtained with the $\mathrm{ZnPc}^{\mathrm{R}}$ alone indicating a weak electrocatalytic effect. The AuNPtOcBr-S-ZnPc ${ }^{\mathrm{R}}$ covalent adduct did not show any electrocatalytic effect in the cathodic process. These values are similar to those obtained with other sensors modified with nanoparticles or phthalocyanines separately $[2,10,36,38,41,42]$.

Results were completely different in the anodic wave. LODs calculated from the anodic peaks, showed that the sensor modified with the covalent adduct gave the lowest LOD values $\left(1.38 \times 10^{-7} \mathrm{~mol} \cdot \mathrm{L}^{-1}\right)$, confirming the strong influence of the covalent bond in the mechanism of catechol oxidation. This result indicates that the covalent interaction facilitated the electron transfer during oxidation and that the nature of the interaction between both components (weak bond in the mixture or covalent bond in the adduct) modulates the catalytic activity.

\section{Conclusions}

New voltammetric sensors based on combinations of gold nanoparticles and sulfur substituted zinc phthalocyanines have been developed and used as electrochemical sensors for the detection of catechol. The electron transfer process, as well as the existence of synergistic effects between both components in the absence and presence of covalent links has been analyzed.

It has been demonstrated that the electrocatalytic properties and the kinetic parameters depend on the type of interaction between both components. The AuNPtOcBr$/ \mathrm{ZnPc}^{\mathrm{RS}}$ and the

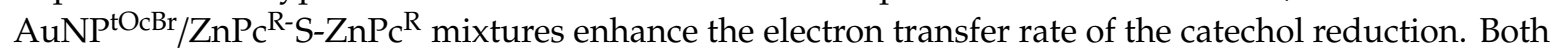
modifiers showed similar LODs of $10^{-6} \mathrm{~mol} \cdot \mathrm{L}^{-1}$. As in the dimeric phthalocyanine the sulfur group is blocked, it can be inferred that the sulfur group does not play a role in the electrocatalytic process. In turn, the AuNP ${ }^{\mathrm{tOcBr}}-\mathrm{S}-\mathrm{ZnPc}{ }^{\mathrm{R}}$ covalent adduct facilitates the oxidation of catechol, showing an enhanced charge transfer rate, and an LOD of $10^{-7} \mathrm{~mol} \cdot \mathrm{L}^{-1}$.

Under the light of these results, combining covalently nanoparticles and phthalocyanines can be considered a good strategy to improve the charge transfer rate and the limits of detection of catechol. Future works should be dedicated to analyzing the effect of the interaction between electrocatalytic materials in other systems different than the nanoparticle-phthalocyanine system.

Supplementary Materials: The following are available online at http://www.mdpi.com/2079-4991/9/11/1506/s1.

Author Contributions: Conceptualization, M.L.R.-M., Á.S.-S. and C.G.-C.; methodology, M.L.R.-M.; investigation, Á.I.R.-C., J.O. and C.G.-H.; resources, Á.S.-S. and M.A.R.-P.; data curation, A.I.R.-C. and F.M.-P.; writing-original draft preparation, A.I.R.-C.; writing-review and editing, M.L.R.-M. and Á.S.-S.; funding acquisition, M.L.R.-M. and Á.S.-S.

Funding: Financial support by MINECO-FEDER (RTI2018-097990-B-I00 and CTQ2017-87102-R) and the Junta de Castilla y Leon FEDER (VA275P18) is gratefully acknowledged. 
Acknowledgments: Celia Garcia-Hernandez would also like to thank Junta de Castilla y León for a grant (BOCYL-D-4112015-9).

Conflicts of Interest: The authors declare no conflict of interest.

\section{References}

1. Blasco, A.J.; González Crevillén, A.; González, M.C.; Escarpa, A. Direct Electrochemical Sensing and Detection of Natural Antioxidants and Antioxidant Capacity in Vitro Systems. Electroanalysis 2007, 19, 2275-2286. [CrossRef]

2. Medina-Plaza, C.; García-Cabezón, C.; García-Hernández, C.; Bramorski, C.; Blanco-Val, Y.; Martín-Pedrosa, F.; Kawai, T.; de Saja, J.A.; Rodríguez-Méndez, M.L. Analysis of organic acids and phenols of interest in the wine industry using Langmuir-Blodgett films based on functionalized nanoparticles. Anal. Chim. Acta 2015, 853, 572-578. [CrossRef] [PubMed]

3. Makhotkina, O.; Kilmartin, P.A. The use of cyclic voltammetry for wine analysis: Determination of polyphenols and free sulfur dioxide. Anal. Chim. Acta 2010, 668, 155-165. [CrossRef] [PubMed]

4. Yang, C.; Denno, M.E.; Pyakurel, P.; Venton, B.J. Recent trends in carbon nanomaterial-based electrochemical sensors for biomolecules: A review. Anal. Chim. Acta 2015, 887, 17-37. [CrossRef] [PubMed]

5. Gay Martín, M.; de Saja, J.A.; Muñoz, R.; Rodríguez-Méndez, M.L. Multisensor system based on bisphthalocyanine nanowires for the detection of antioxidants. Electrochim. Acta 2012, 68, 88-94. [CrossRef]

6. Liu, D.; Li, F.; Yu, D.; Yu, J.; Ding, Y.; Liu, D.; Li, F.; Yu, D.; Yu, J.; Ding, Y. Mesoporous Carbon and Ceria Nanoparticles Composite Modified Electrode for the Simultaneous Determination of Hydroquinone and Catechol. Nanomaterials 2019, 9, 54. [CrossRef]

7. Krampa, F.; Aniweh, Y.; Awandare, G.; Kanyong, P.; Krampa, F.D.; Aniweh, Y.; Awandare, G.A.; Kanyong, P. A Disposable Amperometric Sensor Based on High-Performance PEDOT:PSS/Ionic Liquid Nanocomposite Thin Film-Modified Screen-Printed Electrode for the Analysis of Catechol in Natural Water Samples. Sensors 2017, 17, 1716. [CrossRef]

8. Apetrei, C.; Casilli, S.; De Luca, M.; Valli, L.; Jiang, J.; Rodriguez-Méndez, M.L.; De Saja, J.A. Spectroelectrochemical characterisation of Langmuir-Schaefer films of heteroleptic phthalocyanine complexes. Potential applications. Colloids Surfaces A Physicochem. Eng. Asp. 2006, 284-285, 574-582. [CrossRef]

9. Rodriguez-Méndez, M.L.; Gay, M.; de Saja, J.A. New insights into sensors based on radical bisphthalocyanines. J. Porphyr. Phthalocyanines 2009, 13, 1159-1167. [CrossRef]

10. Alessio, P.; Martin, C.S.; de Saja, J.A.; Rodriguez-Mendez, M.L. Mimetic biosensors composed by layer-by-layer films of phospholipid, phthalocyanine and silver nanoparticles to polyphenol detection. Sens. Actuators $B$ Chem. 2016, 233, 654-666. [CrossRef]

11. Matemadombo, F.; Apetrei, C.; Nyokong, T.; Rodríguez-Méndez, M.L.; de Saja, J.A. Comparison of carbon screen-printed and disk electrodes in the detection of antioxidants using CoPc derivatives. Sens. Actuators $B$ Chem. 2012, 166, 457-466. [CrossRef]

12. Fernandes, E.G.R.; Brazaca, L.C.; Rodríguez-Mendez, M.L.; Saja, J.A.; de Zucolotto, V. Immobilization of lutetium bisphthalocyanine in nanostructured biomimetic sensors using the LbL technique for phenol detection. Biosens. Bioelectron. 2011, 26, 4715-4719. [CrossRef] [PubMed]

13. Zagal, J.H.; Griveau, S.; Silva, J.F.; Nyokong, T.; Bedioui, F. Metallophthalocyanine-based molecular materials as catalysts for electrochemical reactions. Coord. Chem. Rev. 2010, 254, 2755-2791. [CrossRef]

14. Tkachenko, N.V.; Efimov, A.; Lemmetyinen, H. Covalent phthalocyanine-fullerene dyads: Synthesis, electron transfer in solutions and molecular films. J. Porphyr. Phthalocyanines 2011, 15, 780-790. [CrossRef]

15. Martín-Gomis, L.; Peralta-Ruiz, F.; Thomas, M.B.; Fernández-Lázaro, F.; D’Souza, F.; Sastre-Santos, Á. Multichromophoric Perylenediimide-Silicon Phthalocyanine-C 60 System as an Artificial Photosynthetic Analogue. Chem. A Eur. J. 2017, 23, 3863-3874. [CrossRef]

16. Fukuzumi, S.; Ohkubo, K.; Ortiz, J.; Gutiérrez, A.M.; Fernández-Lázaro, F.; Sastre-Santos, Á. Control of Photoinduced Electron Transfer in Zinc Phthalocyanine-Perylenediimide Dyad and Triad by the Magnesium Ion. J. Phys. Chem. A 2008, 112, 10744-10752. [CrossRef]

17. Blas-Ferrando, V.M.; Ortiz, J.; Ohkubo, K.; Fukuzumi, S.; Fernández-Lázaro, F.; Sastre-Santos, Á. Submillisecond-lived photoinduced charge separation in a fully conjugated phthalocyanineperylenebenzimidazole dyad. Chem. Sci. 2014, 5, 4785-4793. [CrossRef] 
18. Aragão, J.S.; Ribeiro, F.W.P.; Portela, R.R.; Santos, V.N.; Sousa, C.P.; Becker, H.; Correia, A.N.; de Lima-Neto, P. Electrochemical determination diethylstilbestrol by a multi-walled carbon nanotube/cobalt phthalocyanine film electrode. Sens. Actuators B Chem. 2017, 239, 933-942. [CrossRef]

19. Jubete, E.; Żelechowska, K.; Loaiza, O.A.; Lamas, P.J.; Ochoteco, E.; Farmer, K.D.; Roberts, K.P.; Biernat, J.F. Derivatization of SWCNTs with cobalt phthalocyanine residues and applications in screen printed electrodes for electrochemical detection of thiocholine. Electrochim. Acta 2011, 56, 3988-3995. [CrossRef]

20. Nombona, N.; Antunes, E.; Litwinski, C.; Nyokong, T. Synthesis and photophysical studies of phthalocyanine-gold nanoparticle conjugates. Dalt Trans. 2011, 40, 11876-11884. [CrossRef]

21. Blas-Ferrando, V.M.; Ortiz, J.; Fernández-Lázaro, F.; Sastre-Santos, Á. Synthesis and characterization of a sulfur-containing phthalocyanine-gold nanoparticle hybrid. J. Porphyr. Phthalocyanines 2015, 19, 335-343. [CrossRef]

22. Baldovi, H.G.; Blas-Ferrando, V.M.; Ortiz, J.; Garcia, H.; Fernández-Lázaro, F.; Sastre-Santos, Á. Phthalocyanine-Gold Nanoparticle Hybrids: Modulating Quenching with a Silica Matrix Shell. ChemPhysChem 2016, 17, 1579-1585. [CrossRef] [PubMed]

23. Pan, X.; Liang, X.; Yao, L.; Wang, X.; Jing, Y.; Ma, J.; Fei, Y.; Chen, L.; Mi, L.; Pan, X.; et al. Study of the Photodynamic Activity of N-Doped TiO2 Nanoparticles Conjugated with Aluminum Phthalocyanine. Nanomaterials 2017, 7, 338. [CrossRef] [PubMed]

24. Pingarrón, J.M.; Yáñez-Sedeño, P.; González-Cortés, A. Gold nanoparticle-based electrochemical biosensors. Electrochim. Acta 2008, 53, 5848-5866. [CrossRef]

25. Saha, K.; Agasti, S.S.; Kim, C.; Li, X.; Rotello, V.M. Gold Nanoparticles in Chemical and Biological Sensing. Chem. Rev. 2012, 112, 2739-2779. [CrossRef]

26. Yu, C.; Wang, Q.; Qian, D.; Li, W.; Huang, Y.; Chen, F.; Bao, N.; Gu, H. An ITO electrode modified with electrodeposited graphene oxide and gold nanoclusters for detecting the release of $\mathrm{H} 2 \mathrm{O} 2$ from bupivacaine-injured neuroblastoma cells. Microchim. Acta 2016, 183, 3167-3175. [CrossRef]

27. Singh, S.; Jain, D.S.M. Sol-gel based composite of gold nanoparticles as matix for tyrosinase for amperometric catechol biosensor. Sens. Actuators B Chem. 2013, 182, 161-169. [CrossRef]

28. Medina-Plaza, C.; Rodriguez-Mendez, M.L.; Sutter, P.; Tong, X.; Sutter, E. Nanoscale Au-In Alloy-Oxide Core-Shell Particles as Electrocatalysts for Efficient Hydroquinone Detection. J. Phys. Chem. C 2015, 119, 25100-25107. [CrossRef]

29. Lin, X.; Ni, Y.; Kokot, S. Glassy carbon electrodes modified with gold nanoparticles for the simultaneous determination of three food antioxidants. Anal. Chim. Acta 2013, 765, 54-62. [CrossRef]

30. Li, X.; Ye, X.; Li, C.; Wu, K. Substitution group effects of 2-mercaptobenzothiazole on gold nanoparticles toward electrochemical oxidation and sensing of tetrabromobisphenol A. Electrochim. Acta 2018, 270, 517-525. [CrossRef]

31. Steinebrunner, D.; Schnurpfeil, G.; Wichmann, A.; Wöhrle, D.; Wittstock, A. Synergistic Effect in Zinc Phthalocyanine-Nanoporous Gold Hybrid Materials for Enhanced Photocatalytic Oxidations. Catalysts 2019, 9, 555. [CrossRef]

32. Nyokong, T.; Antunes, E. Influence of nanoparticle materials on the photophysical behavior of phthalocyanines. Coord. Chem. Rev. 2013, 257, 2401-2418. [CrossRef]

33. Gonzalez-Anton, R.; Osipova, M.M.; Garcia-Hernandez, C.; Dubinina, T.V.; Tomilova, L.G.; Garcia-Cabezon, C.; Rodriguez-Mendez, M.L. Subphthalocyanines as electron mediators in biosensors based on phenol oxidases: Application to the analysis of red wines. Electrochim. Acta 2017, 255, 239-247. [CrossRef]

34. Muthukumar, P.; Abraham John, S. Synergistic effect of gold nanoparticles and amine functionalized cobalt porphyrin on electrochemical oxidation of hydrazine. New J. Chem. 2014, 38, 3473-3479. [CrossRef]

35. Muthukumar, P.; John, S.A. Effect of amine substituted at ortho and para positions on the electrochemical and electrocatalytic properties of cobalt porphyrins self-assembled on glassy carbon surface. Electrochim. Acta 2014, 115, 197-205. [CrossRef]

36. Medina-Plaza, C.; Furini, L.N.; Constantino, C.J.L.; De Saja, J.A.; Rodriguez-Mendez, M.L. Synergistic electrocatalytic effect of nanostructured mixed films formed by functionalised gold nanoparticles and bisphthalocyanines. Anal. Chim. Acta 2014, 851, 95-102. [CrossRef] 
37. Alessio, P.; Aoki, P.H.B.; De Saja Saez, J.A.; Rodríguez-Méndez, M.L.; Constantino, C.J.L. Combining SERRS and electrochemistry to characterize sensors based on biomembrane mimetic models formed by phospholipids. RSC Adv. 2011, 1, 211-218. [CrossRef]

38. García-Hernández, C.; García-Cabezón, C.; Medina-Plaza, C.; Martín-Pedrosa, F.; Blanco, Y.; de Saja, J.A.; Rodríguez-Méndez, M.L. Electrochemical behavior of polypyrrol/AuNP composites deposited by different electrochemical methods: Sensing properties towards catechol. Beilstein J. Nanotechnol. 2015, 6, 2052-2061. [CrossRef]

39. Brust, M.; Walker, M.; Bethell, D.; Schiffrin, D.J.; Whyman, R.; Kirkland, A.I.; Logan, D.E. Synthesis of thiol-derivatised gold nanoparticles in a two-phase Liquid?Liquid system. J. Chem. Soc. Chem. Commun. 1994, 7, 801-802. [CrossRef]

40. Roth, P.J.; Theato, P. Versatile Synthesis of Functional Gold Nanoparticles: Grafting Polymers From and Onto. Chem. Mater. 2008, 20, 1614-1621. [CrossRef]

41. Alessio, P.; Pavinatto, F.J.; Oliveira, O.N.; de Saja, J.A.; Constantino, J.C.L.; Rodriguez-Mendez, M.L. Detection of catechol using mixed Langmuir-Blodgett films of a phospholipid and phthalocyanines as voltammetric sensors. Analyst 2010, 135, 2591-2599. [CrossRef] [PubMed]

42. Maximino, M.D.; Martin, C.S.; Paulovich, F.V.; Alessio, P. Layer-by-Layer Thin Film of Iron Phthalocyanine as a Simple and Fast Sensor for Polyphenol Determination in Tea Samples. J. Food. Sci. 2016, 81, C2344-C2351. [CrossRef] [PubMed]

(C) 2019 by the authors. Licensee MDPI, Basel, Switzerland. This article is an open access article distributed under the terms and conditions of the Creative Commons Attribution (CC BY) license (http://creativecommons.org/licenses/by/4.0/). 